\title{
Chitin Beads from Peneaus sp. Shells as a Biosorbent for Methylene Blue Dye Removal
}

\author{
M. Millicent Mabel ${ }^{1 *}$, T.R. Sundararaman ${ }^{1}$, N. Parthasarathy ${ }^{2}$, Johanna Rajkumar ${ }^{1}$ \\ ${ }^{1}$ Department of Biotechnology, Rajalakshmi Engineering College, Thandalam, Chennai, TamilNadu, India \\ ${ }^{2}$ Department of Biotechnology, Prathyusha Engineering College, Aranvoyalkuppam, Tiruvallur, TamilNadu, India
}

Received: 8 December 2017

Accepted: 23 April 2018

\begin{abstract}
The adsorption potential of chitin, a polysaccharide found in the exoskeleton of shrimp, was evaluated using methylene blue cationic dye. Batch adsorption studies were done using a column by optimized bed height of $22.2 \mathrm{~cm}$ and retention time of $90 \mathrm{~min}$. The alginate:chitin ratio was taken as 1:07 with $80 \mathrm{mgl}-1$ initial dye concentration, and $\mathrm{pH}$ was maintained at 8 . There was $90 \%$ adsorption of dye. Langmuir and Freundlich isotherms were studied along with the adsorption kinetics. The plots indicated that the data fitted Langmuir isotherm. The $\mathrm{R}^{2}$ is greater for pseudo second-order kinetics and Weber and Morris' model on intra particle diffusion best fit this adsorption by chitin.
\end{abstract}

Keywords: adsorption, chitin, isotherms, kinetics, methylene blue

\section{Introduction}

The textile and leather industries require dyes to impart colour to many products, but dye effluents from these industries have hazardous environmental effects. More than 100,000 commercial dyes are available to the textile industries worldwide. $10-25 \%$ of textile dyes are lost during the dyeing process and around $20 \%$ effluents mix with various environmental components, causing harm if they are not treated properly. The double bonds and aromatic rings in the chemical structure of dyes are difficult to degrade because it can resist heat up to $300^{\circ} \mathrm{C}[1]$.

Methylene blue, a cationic dye with molecular weight $373.90 \mathrm{gmol}^{-1}$, is commonly used in the textile and leather industries. In humans, methylene blue may

*e-mail: millicentmable.m@rajalakshmi.edu.in cause hazardous effects like tachycardia, nausea, blue coloration of skin, and death of premature cells in the tissues [2]. Adsorption is the best process for textile dye effluent treatment. It commonly uses activated carbon as an adsorbent but it cannot be used in industries because of its expensive operational costs and low regeneration capacity. Hence, there is rigorous research for developing a cheap material as adsorbents of these textile dyes. Bio-sorbents like marine plants, humus, moss peat, modified cotton, chitin, and chitosan are alternating resources used for exclusion of toxic effluents from industries [3].

Chitin is a naturally abundant and renewable polymer as it is degradable, bio compactable, and a nontoxic adsorbent. Chitin structure has $\beta-(1-4)-$ 2 -acetamido-2-deoxy- $\beta$-D-glucose $[4], \quad$ whereinC-2 position has acetamide groups (Fig. 1). Commercial shells of arthropods (exoskeletons) are the major source from which chitin is obtained - especially of crabs and shrimp [5]. 


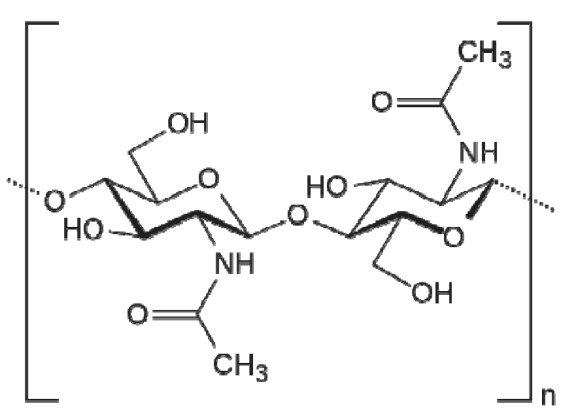

Fig. 1. Chitin structure.

This study was done to adsorb methylene blue dye using chitin obtained from shrimp exoskeleton wastes, and also to study isotherm and kinetic models to determine the favourable method of adsorption. There is a waste-to-wealth approach in this system of study as procuring the raw material chitin is inexpensive since it is a waste product of seafood export industries.

\section{Materials and Methods}

\section{Preparation of Adsorbent}

One percent sodium alginate (Hi-Media) was prepared by warming it continuously in distilled water for the alginate to get dissolved completely. This was followed by the addition of $2 \mathrm{~g}$ of chitin (Hi-Media) powder with continuous stirring. The chitin-alginate mixture was then added as droplets in $5 \%$ calcium chloride solution using a sterile dropper.

\section{Methylene Blue Standard Preparation}

Methylene blue stock (Hi-Media) of $100 \mathrm{mgl}^{-1}$ was prepared, and this solution was used for the standardization process. A UV-visible spectrophotometer reading was taken at $660 \mathrm{~nm}$, (Perkin Elmer, Lambda 25, USA) and this stock solution was used for further optimization experiments.

\section{Optimization of Dye Adsorption}

The retention time was optimized by packing $115 \mathrm{~g}$ of chitin beads to a bed height of $22.2 \mathrm{~cm}$ in a $42 \mathrm{~cm}$ column $(37 \mathrm{~cm}$ working column $+5 \mathrm{~cm}$ head space; bed height:column height $=0.6$ ). Dye stock solution was fed into the column, and the system was kept undisturbed. After $10 \mathrm{~min}$ the sample was eluted, and absorbance was read at $660 \mathrm{~nm}$. The experiment was repeated for every $20 \mathrm{~min}$ till $120 \mathrm{~min}$. Similarly, optimal adsorption efficiency was determined by varying bed height $(7.4 \mathrm{~cm}, 11.1 \mathrm{~cm}, 14.8 \mathrm{~cm}, 18.5 \mathrm{~cm}$, and $22.2 \mathrm{~cm})$, $\mathrm{pH}$ (4 to 10), alginate:chitin ratio $(1: 2,1: 3,1: 4,1: 5,1: 6$, 1:7, 1:8, and 1:9), and dye concentration $\left(20 \mathrm{mg} \mathrm{l}^{-1}\right.$ to $\left.100 \mathrm{mg}^{-1}\right)$. Removal efficiency of chitin is:
Removal efficiency $=\left[\left(C_{0}-C_{t}\right) / C_{o}\right] * 100$

...where $\mathrm{C}_{\mathrm{o}}$ is the initial concentration of methylene blue and $\mathrm{C}_{t}$ is the solution concentration after adsorption at any time [6].

\section{Isotherms of Chitin Methylene Blue Adsorption}

Langmuir [7] established batch adsorption isotherm for surface adsorption relating the concentration of adsorbate initially and after adsorption, which is expressed as:

$$
\mathrm{C}_{\mathrm{e}} \mathrm{Q}_{\mathrm{e}}=\mathrm{C}_{\mathrm{e}} / \mathrm{Q}_{\mathrm{m}}+1 / \mathrm{Q}_{\mathrm{m}} \mathrm{b}
$$

...where $\mathrm{C}_{\mathrm{e}}$ is the equilibrium concentration of dye in solution ( $\left.\mathrm{mg} \mathrm{l}^{-1}\right), \mathrm{Q}_{\mathrm{e}}$ is the amount of dye adsorbed on the adsorbent at equilibrium ( $\left.\mathrm{mg} \mathrm{g}^{-1}\right), \mathrm{Q}_{\mathrm{m}}$ is the monolayer adsorption capacity $\left(\mathrm{mg} \mathrm{g}^{-1}\right)$, and $\mathrm{b}$ is the Langmuir constant $\left(1 \mathrm{mg}^{-1}\right)[8]$ :

$$
\mathrm{Q}_{\mathrm{e}}=\left(\mathrm{C}_{\mathrm{o}}-\mathrm{C}_{\mathrm{e}}\right) \mathrm{V} / \mathrm{m}
$$

...where $\mathrm{C}_{\mathrm{o}}$ and $\mathrm{C}_{\mathrm{e}}\left(\mathrm{mg} \mathrm{l}^{-1}\right)$ are the liquid-phase residual concentrations of dye at initial and equilibrium, respectively. V is the volume of the solution (l) and $\mathrm{W}$ is the mass of dry sorbent used (g) [9].

Separation factor $R_{L}[10]$ was used to test the validity of Langmuir isotherm and was calculated as follows:

$$
\mathrm{R}_{\mathrm{L}}=1 /\left(1+\mathrm{bC}_{\mathrm{o}}\right)
$$

...where $\mathrm{C}_{\mathrm{o}}$ is the initial concentration of dye and $\mathrm{b}$ is the Langmuir constant [8].

Freundlich isotherm [11] for this process is:

$$
\log Q_{e}=\log K_{f}+1 / n \log C_{e}
$$

$\mathrm{K}_{\mathrm{f}}$ and $\mathrm{n}$ are constants [8].

\section{Adsorption Kinetics}

The dye adsorption kinetic and intra particle diffusion study on chitin beads was done [12-14].

\section{FTIR of Chitin Beads}

Fourier transform infrared (FTIR) characterization of chitin and methylene blue was done. $\mathrm{KBr}$ disks of chitin beads were prepared and the functional groups present were graphically identified using an ASCII PEDS 1.60 FTIR spectroscope in the range of 4000 to $400 \mathrm{~cm}^{-1}$. 


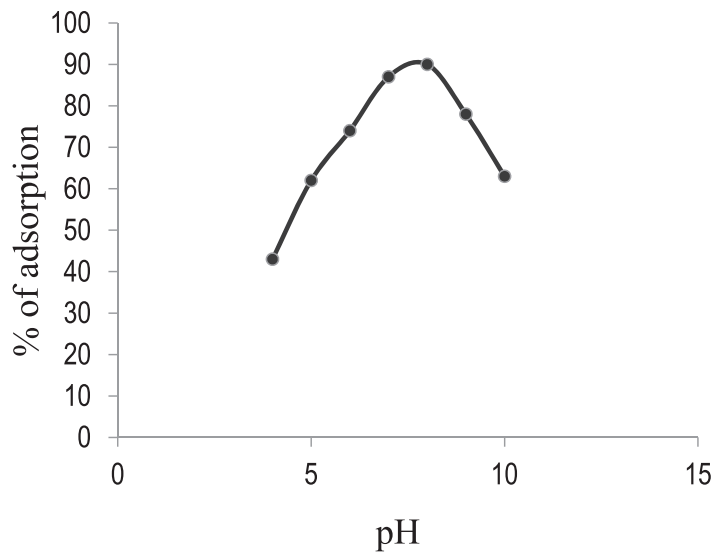

Fig. 2. Chitin beads adsorbing methylene blue dye at different $\mathrm{pH}$.

\section{Results and Discussion}

\section{Chitin Beads Adsorbing Dye at Different Initial $\mathrm{pH}$}

Fig. 2 shows the trend of dye adsorption with varying $\mathrm{pH}$ that contributes to the ionization of chitin and methylene blue. There was $90 \%$ maximum adsorption at $\mathrm{pH} 8$ [15] for the dye concentration of $80 \mathrm{mgl}^{-1}$, and this was considered the optimal level for further experiments. The cations are adsorbed at $\mathrm{pH}>\mathrm{pHzpc}$ of chitin, while anions are adsorbed at $\mathrm{pH}<\mathrm{pHzpc}$ of chitin, and pHzpc of chitin was found to be 6 [16]. It has also been reported by Dotto et al. [17] that at higher $\mathrm{pH}$, negatively charged deprotonated chitin have attractive electrostatic interaction with positively charged methylene blue dye. From $\mathrm{pH} 4$ to 8 there was an increase in adsorption, but it decreased with further $\mathrm{pH}$ increase. This is because the decrease in negatively charged sites on the chitin beads (increased cationic dye molecules), thereby resulting in electrostatic repulsion [18]. Alzaydien et al. [19] and Saed et al. [20] stated that the concentration of $\mathrm{H}^{+}$ions determines the adsorption and also obtained similar results.

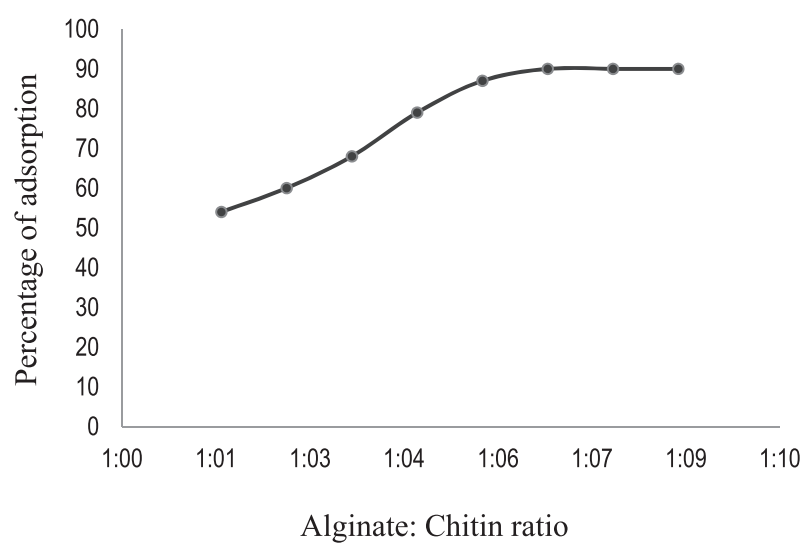

Fig. 3. Chitin beads adsorbing methylene blue dye; different ratios of alginate:chitin.

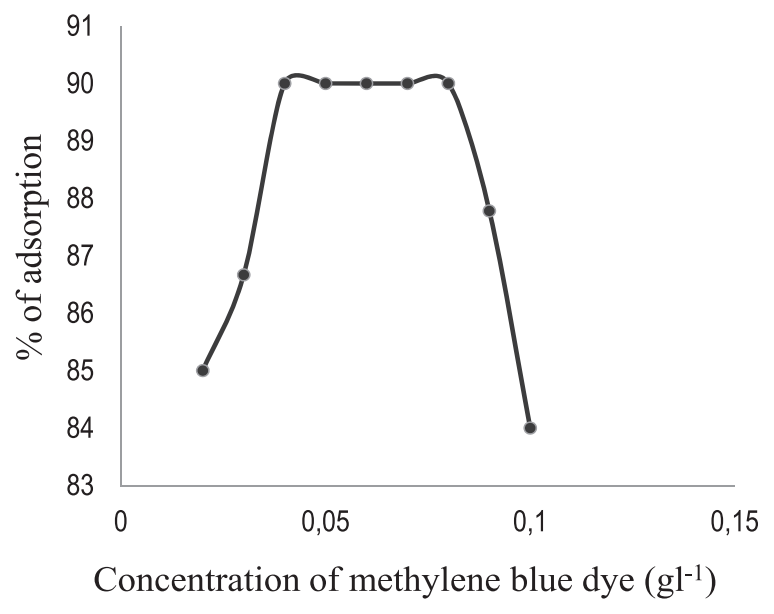

Fig. 4. Chitin beads adsorbing methylene blue dye at different dye concentrations.

\section{Different Dosage Ratios of Alginate:Chitin}

A plot of alginate:chitin ratios and adsorption percentages are shown in Fig. 3, and 1:07 ratio of alginate:chitin was identified as optimum ratio. There was no further adsorption with increased concentration of chitin. Jeyavathana et al. [21] suggested that decreased particle size and increased chitin dosage is a driving force for adsorbate that goes deep inside the pores to bind to the chitin. In a study by Unal et al. [22] using waste Elaeagnus stone, the adsorption increased with the increase in concentration of dosage, but the optimum level was comparatively lower than chitin:alginate.

\section{Chitin Beads Adsorbing Dye at Different Dye Doncentrations}

$90 \%$ adsorption was observed (Fig. 4) at $40 \mathrm{mgl}^{-1}$, remained the same until $80 \mathrm{mgl}^{-1}$, and started decreasing at $100 \mathrm{mgl}^{-1}$. To make the process efficient, a higher dye concentration of $80 \mathrm{mgl}^{-1}$ was considered optimal. Jirekar et al. [23] used $100 \mathrm{mgl}^{-1}$ of green gram obtaining only $79.85 \%$ adsorption and Rahman et al. [24] using $4 \mathrm{mgl}^{-1}$ on rice husk obtained around $70 \%$ adsorption only, although EI-Waki et al. [25] reported around 95 to $98 \%$ with activated carbon from papyrus plant treated with chemicals. Initially the adsorbent has many unoccupied active sites, hence adsorption increases. After maximum adsorption capacity is reached the binding sites become unavailable and there is no further change in adsorption [5].

\section{Chitin Beads Adsorbing Dye at Regular Interval of Time}

Chitin beads adsorbing methylene blue dye at different time intervals is graphically represented in Fig. 5. As the retention time of the dye increased, 


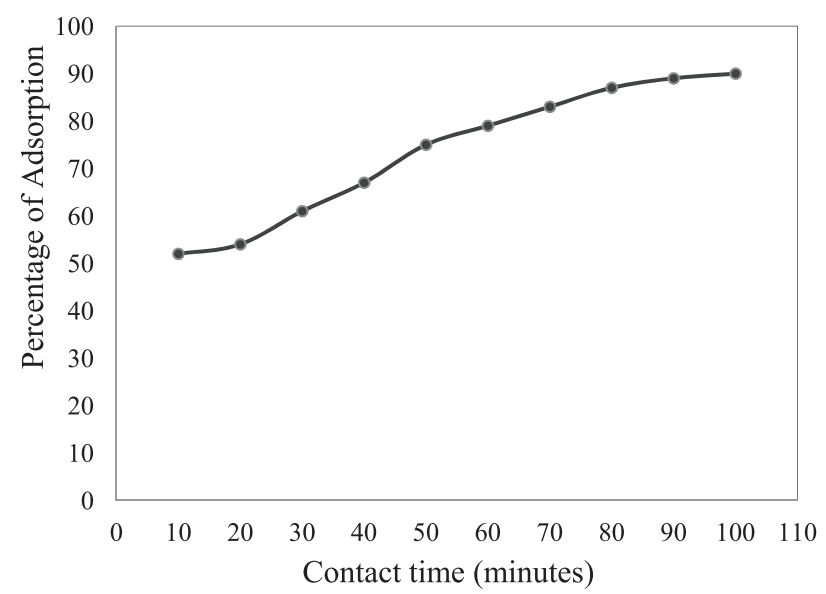

Fig. 5. Chitin beads adsorbing methylene blue dye at regular time intervals.

the percentage of adsorption increased. At $90 \mathrm{~min}$, a maximum adsorption of $90 \%$ of dye was observed and it remained the same further during the process. The adsorption process occurs in three steps, namely boundary layer diffusion, surface adsorption, and pore diffusion. Hence, it takes a longer time for optimal adsorption to take place [26]. Shehata [8] also stated that the adsorption process took reasonably long retention time due to the three steps in adsorption, and the maximum absorption at 90 min using animal bone was obtained. El-Maghraby and El Deeb [27] used rice hulls and obtained maximum methylene blue adsorption at 90 min. Activated carbon from shells of Pongamia Pinnata seeds also showed similar results with a faster rate of adsorption initially [28].

\section{Chitin Beads Packing at Different Bed Heights}

The adsorption percentage of dye by chitin beads increases as the bed height increases, which is shown in Fig. 6. At $22.2 \mathrm{~cm}$ there was a maximum adsorption of $90 \%$ (working volume:reactor volume $=0.6$ ). Timi Tarawou et al. [29] also proved that as the height increases, $100 \%$ adsorption of the dye is possible but the

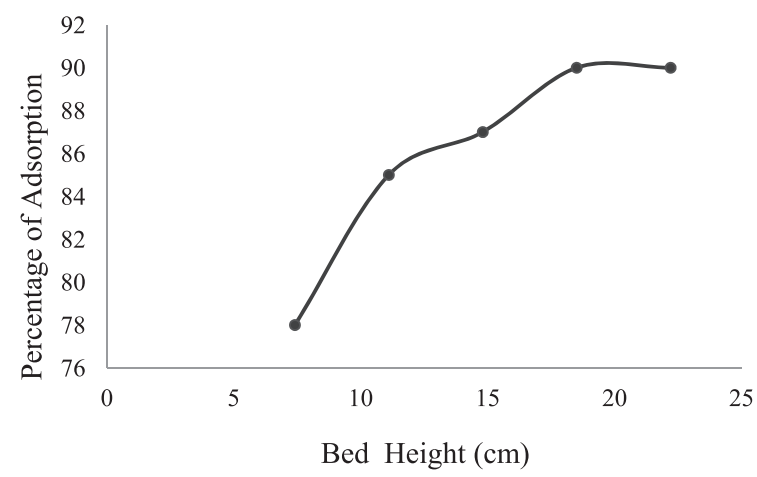

Fig. 6. Chitin beads adsorbing methylene blue dye; chitin bead packing at different bed heights.

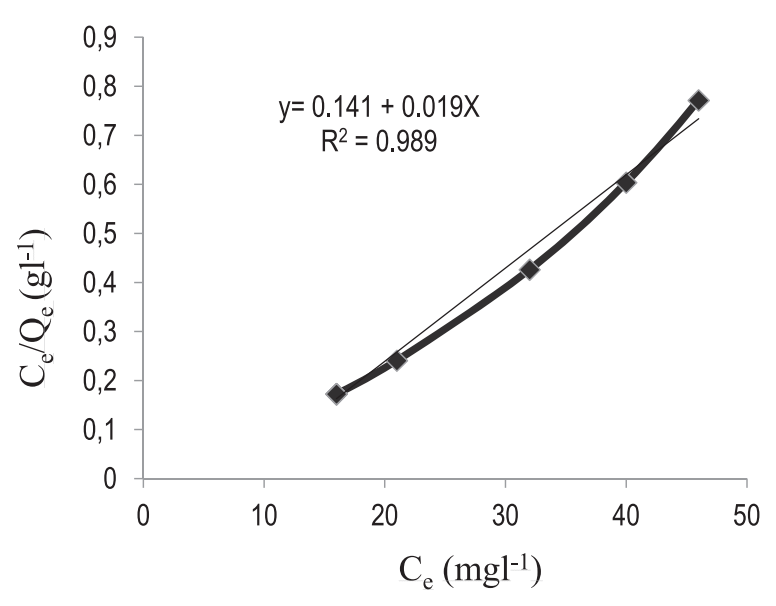

Fig. 7. Chitin beads adsorbing methylene blue dye; Langmuir isotherm for dye adsorption.

time taken for the process also increases. Jabbar et al. [30] used a granulated activated carbon bed at different heights and obtained maximum adsorption as the height increased because of the availability of plenty of surface area and time for reaching saturation level.

\section{Isotherms for Dye Adsorption}

A plot for methylene blue dye Langmuir isotherm is shown in Fig. 7. Ce/Qe was plotted against $\mathrm{Ce}$, the amount of dye adsorbed onto beads, and at varied concentration of the adsorbent a linear plot was obtained. The adsorption process fits Langmuir isotherm when $0<$ $\mathrm{R}^{2}<1$ and preferably when $\mathrm{R}^{2} 0.98$ [31]. Table 1 reveals that $\mathrm{R}^{2}=0.98$, and it fitted the Langmuir isotherm and also that the process was favourable.

Further confirmation of the process feasibility can be analysed by separation factor, $\mathrm{R}_{\mathrm{L}}$. Fig. 8 shows variation of $\mathrm{R}_{\mathrm{L}}$ with the quantity of methylene blue adsorbed at varying chitin concentrations $\left(\mathrm{C}_{\mathrm{e}}\right)$. Adsorption

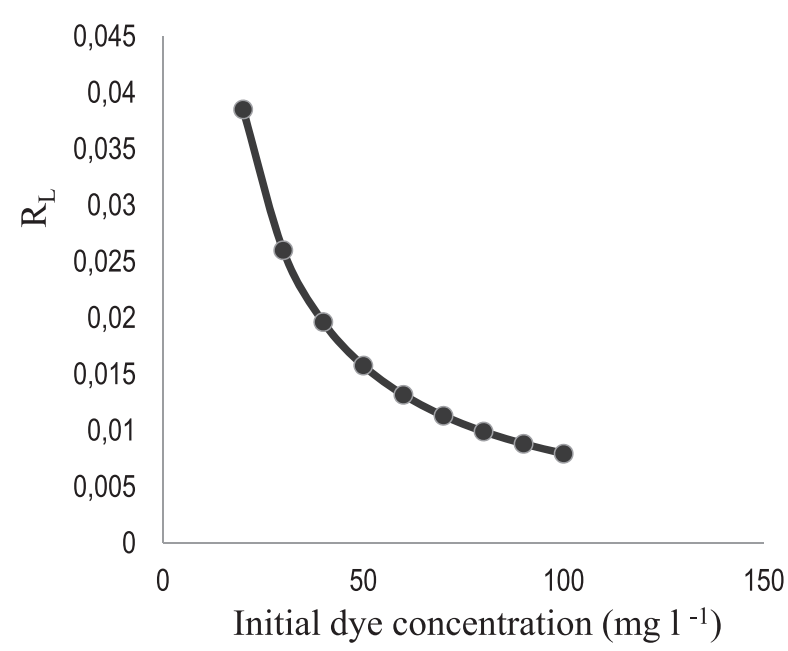

Fig. 8. Chitin beads adsorbing methylene blue dye; determining separation factor from Langmuir isotherm for dye adsorption. 
Table 1. Chitin beads adsorbing methylene blue dye; implications of adsorption isotherms.

\begin{tabular}{|c|c|c|c|c|c|c|}
\hline Types of isotherm & Favourable conditions & $\begin{array}{c}\mathrm{Q}_{\mathrm{m}} \\
\left.\mathrm{mg} \mathrm{g}^{-1}\right)\end{array}$ & $\begin{array}{c}\mathrm{b} \\
\left(1 \mathrm{mg}^{-1}\right)\end{array}$ & $\begin{array}{c}\mathrm{K}_{\mathrm{f}} \\
\left(\mathrm{mg} \mathrm{g}^{-1}\right)\end{array}$ & $\mathrm{n}$ & $\mathrm{R}^{2}$ \\
\hline Langmuir isotherm & $\begin{array}{c}0<\mathrm{R}^{2}<1 \\
\mathrm{R}^{2} \text { close to } 1\end{array}$ & 52.63 & 0.13 & - & - & 0.989 \\
\hline Freundlich isotherm & $\begin{array}{c}1<\mathrm{n}<10 \\
\mathrm{R}^{2} \text { close to } 1\end{array}$ & - & - & 3.10 & 2 & 0.974 \\
\hline
\end{tabular}

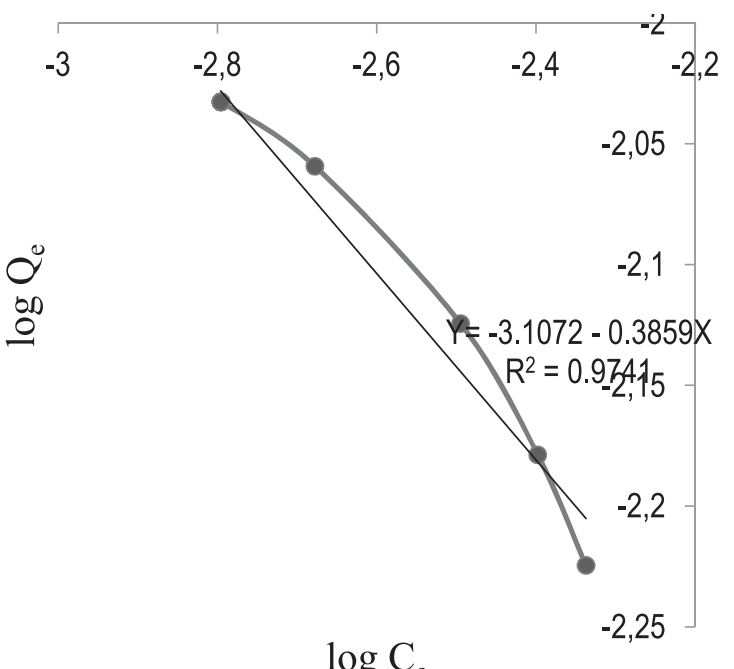

Fig. 9. Chitin beads adsorbing methylene blue dye; Freundlich isotherm for dye adsorption.

is considered favourable when $0<R_{L}<1$, linear if $\mathrm{R}_{\mathrm{L}}=1$, and irreversible if $\mathrm{R}_{\mathrm{L}}=0$ [32]. It is proved to be favourable with the experimental data from Table $1 . \mathrm{R}^{2}=0.974$ and $\mathrm{n}=2$ was obtained from a graph of $\ln \mathrm{Q}_{\mathrm{e}}$ vs. $\ln \mathrm{C}_{\mathrm{e}}$ plotted for Freundlich isotherm (Fig. 9). It was comparatively lesser than the $\mathrm{R}^{2}$ value obtained in the Langmuir isotherm. Muhammad [33] reported favourable adsorption conditions when the value of ' $n$ ' between 2-10, inconvenient for $\mathrm{n}=1-2$ and unsuitable for $\mathrm{n}<1 . \mathrm{R}^{2}$ value and adsorption capacity from the Langmuir isotherm were better than those obtained from the Freundlich isotherm.

Experimentally there is homogeneous, uniform adsorption due to equal activation energy for both methylene blue and chitin, hence fitting Langmuir's model. Similar results favouring Langmuir isotherm were observed by Neerajet et al. [34] using coal fly ash, Yu-Shan Hoet et al. [35] with Delonix regia pods, and Danielet et al. [36] from plant litters.

\section{Kinetics of Dye Adsorption}

Fig. 10(a-b) is a plot for chitin and methylene blue kinetics, and Table 2 represents its $\mathrm{R}^{2}, \mathrm{~K}_{1}$, and $\mathrm{K}_{2}$ values. From the graph it is inferred that adsorption data fits pseudo second-order kinetics as $\mathrm{R}^{2}$ value was high, which also was reported by Huayueet et al.
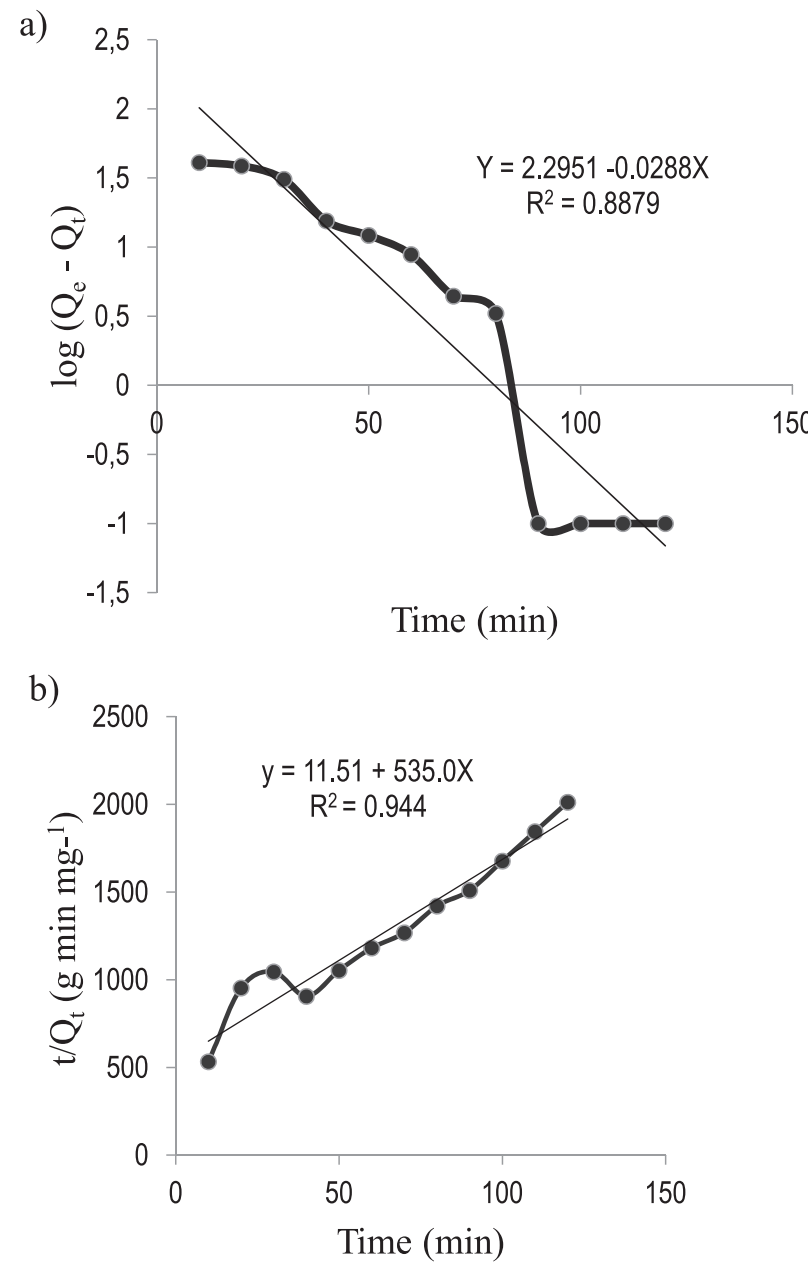

Fig. 10 a) Chitin beads adsorbing methylene blue dye; pseudo first-order kinetics of dye adsorption; b) Chitin beads adsorbing methylene blue dye; pseudo second-order kinetics of dye adsorption.

[37] using chitosan as adsorbent for carcinogenic dye similarly.

A graphical representation of $Q_{t} v s . t^{0.5}$ is shown in Fig. 11, indicating intraparticle diffusion model, and the parameters obtained from the plot are shown in Table 2. The intercept was not zero - clearly indicating a boundary layer effect and intra particle diffusion is the rate-limiting step [38]. Linearity in the graph shows that intraparticle diffusion of dye had taken place and its slope gives rate constant of diffusion. A decline in the intra particle diffusion takes place once the process reaches equilibrium level. 


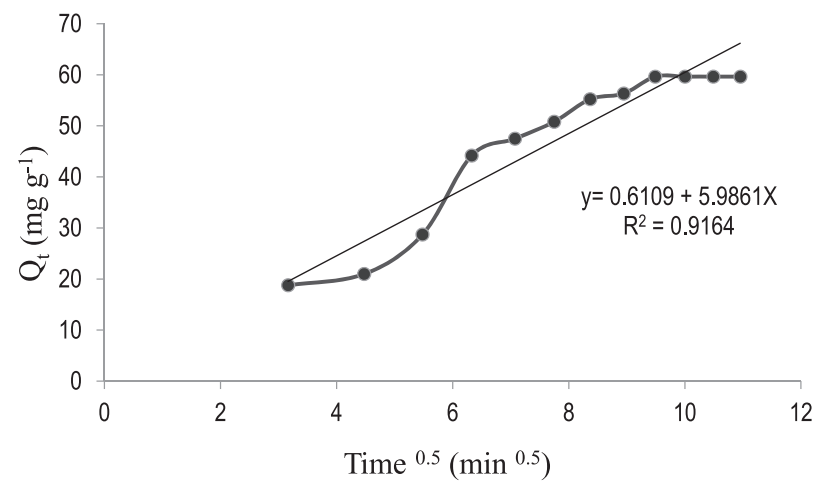

Fig. 11. Chitin beads adsorbing methylene blue dye; intra particle diffusion kinetics of dye adsorption.

Table 2. Chitin beads adsorbing methylene blue dye; kinetics of dye adsorption.

\begin{tabular}{|c|c|c|}
\hline Types of kinetic models & Rate constant & $\begin{array}{c}\text { Correlation } \\
\text { coefficient }\end{array}$ \\
\hline Pseudo first-order & $\mathrm{K}_{1}=0.012 \mathrm{~min}^{-1}$ & 0.88 \\
\hline Pseudo second-order & $\mathrm{K}_{2}=535 \mathrm{~min}^{-1}$ & 0.94 \\
\hline $\begin{array}{c}\text { Intra-particle diffusion } \\
\mathrm{t}^{0.5}=4.15 \mathrm{~min} \\
\mathrm{C}=0.61\end{array}$ & $\mathrm{~K}_{\mathrm{id}}=5.98 \mathrm{mg} \mathrm{g}^{-1} \mathrm{~min}^{-1}$ & 0.91 \\
\hline
\end{tabular}

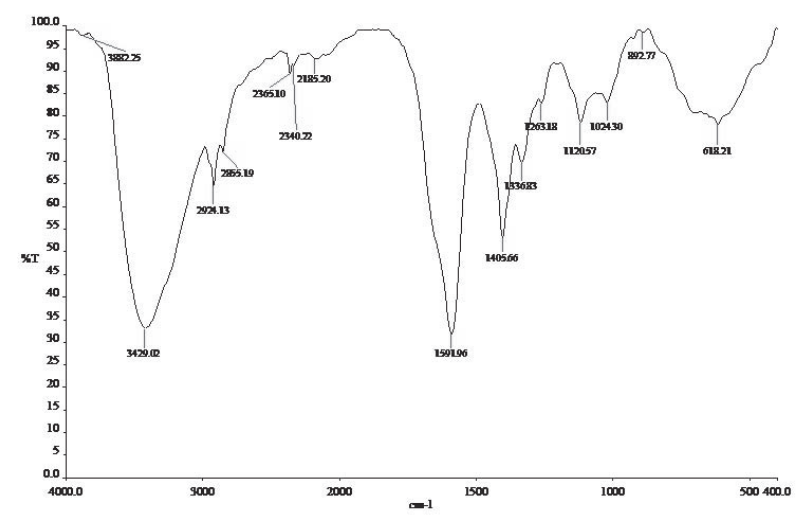

Fig. 12. FTIR of chitin.

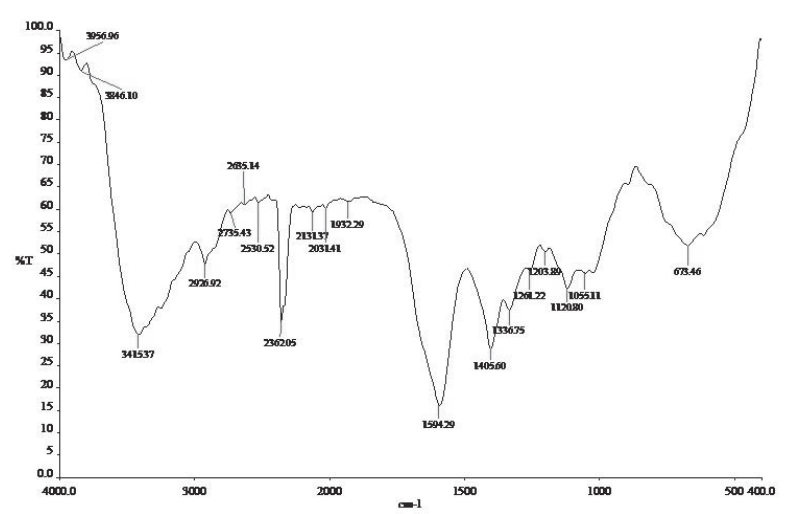

Fig. 13. FTIR of chitin-methylene blue.

\section{FTIR Analysis}

FTIR spectra were analysed for chitin initially and along with methylene blue (Figs 12-13). The $\beta$-glycosidic linkage in the chitin polymer is inferred from the peak at $1120 \mathrm{~cm}^{-1}$. Hydroxyl groups of the carbohydrate are responsible for the broad and strong adsorption around $3429 \mathrm{~cm}^{-1}$. Moreover, the vibrations were observed at $2924 \mathrm{~cm}^{-1}$ for aliphatic C-H stretching as well as $1336 \mathrm{~cm}^{-1}$ for $\mathrm{C}-\mathrm{N}$ stretching, which clearly indicates the structure of chitin.

The aromatic ring vibrations of methylene blue were present at $1405 \mathrm{~cm}^{-1}$ and $1594 \mathrm{~cm}^{-1}$. Weak adsorption at $673 \mathrm{~cm}^{-1}$ indicated $\mathrm{C}-\mathrm{S}$ stretching. A confirmation for adsorption is given by aliphatic $\mathrm{C}-\mathrm{H}$ stretching vibrations at $2926 \mathrm{~cm}^{-1}$ and vibrations at $1336 \mathrm{~cm}^{-1}$ for C-N stretching.

\section{Conclusion}

There was an effective $90 \%$ adsorption by chitin after the optimization of various parameters like retention time, $\mathrm{pH}$, etc. The dye adsorption pattern follows pseudo second-order kinetics and also suggests monolayer adsorption as confirmed by Langmuir isotherm. Hence existing chemical adsorbents used in the effluent treatment system in textile industries can be replaced by chitin alginate beads as a highly effectual nontoxic biopolymer.

\section{Conflict of Interest}

All the authors declare no conflict of interest.

\section{References}

1. FANG YONGLING, ZHONGYU LI, BAOZHU YANG, SONG XU, XIAOJUN HU, QIAOLI LIU, DANDAN HAN, DAYONG LU. Effect of dye structures on optical properties and photocatalytic behaviors of squarainesensitized $\mathrm{TiO}_{2}$ nanocomposites. J. Phys. Chem. C. 118, 16113, 2014.

2. ZEYNOLABEDIN REZVAN, AZAM MARJANI, AREF SHOKRI, MAJID SAGHI, MOHAMMAD HOSEINBIGTAN. Removal of methylene blue dye from aqueous solutions by Elaeagnusan gastifolial as an adsorbent. Oriental Journal of Chemistry. 31, 271, 2015.

3. MOHAMMED M.A., SHITUA., IBRAHIMA. Removal of methylene blue using low cost adsorbent: A Review. Res. J. Chem. Sci. 4, 91, 2014.

4. ZARGAR V., ASGHARI M., DASHTI A. A review on chitin and chitosan polymers: structures, chemistry, solubility, derivatives and applications. Chem Bio Eng Reviews. 2, 204, 2015.

5. YOUNES I., RINAUDO M. Chitin and chitosan preparation from marine sources. structure, properties and applications. Marine Drugs. 13, 1133, 2015.

6. GABRIELA CIOBANU, SIMONA BARNA, MARIA HARJA. Kinetic and equilibrium studies on adsorptionof 
Reactive Blue 19 dye from aqueous solutionsby nanohydroxyapatite adsorbent. Archives of Environmental Protection. 42, 3, 2016.

7. LANGMUIR I. The constitution and fundamental properties of solids and liquids. Part I. Solids. J. Am. Chem. Soc.38, 222, 1916.

8. SHEHATA A.M.A. Removal of methylene blue dye from aqueous solutions by using treated animal bone as a cheap natural adsorbent. International Journal of Emerging Technology and Advanced Engineering.3, 507, 2013.

9. NANGANOAL.T., KETCHA J.M., NDI J.N. Kinetic and equilibrium modeling of the adsorption of amaranth from aqueous solution onto smectite clay. Research Journal of Chemical Sciences. 4, 7, 2014.

10. WEBBER T.W., CHAKRAVORTIR.K. Pore and diffusion models for fixed-bed adsorbers. AIChE Journal.20, 228, 1974.

11. FREUNDLICH H. Over the adsorption in solution. J.Phys. Chem. 57, 385, 1906.

12. LAGERGREN S. About the theory of so-called adsorption of soluble substance. KungligaSvenska Vetenskapsakademiens Handlingar. 24, 1, 1898.

13. PLAZINSKI W., DZIUBA J., RUDZINSKI W. Modeling of sorption kinetics: the pseudo-second order equation and the sorbate intraparticle diffusivity. Adsorption. 19, 1055, 2013.

14. WEBER W.J., MORRISJ.C. Kinetics of adsorption on carbon from solution. Journal of the Sanitary Engineering Division. 89, 31, 1963.

15. AUTA M., HAMEED B.H. Chitosan-clay composite as highly effective and low-cost adsorbent for batch and fixedbed adsorption of methylene blue. Chemical Engineering Journal. 237, 352, 2014.

16. BEGUM H.A., AJOY KANTI MONDAL, TANVIR MUSLIM. Adsorptive removal of reactive black 5 from aqueous solution using chitin prepared from shrimp shells. Bangladesh Pharmaceutical Journal. 15, 145, 2012.

17. DOTTOO G.L., SANTOS J.M.N., RODRIGUES I.L., ROSA R., PAVAN F.A., LIMA E.C.Adsorption of methylene blue by ultrasonic surface modified chitin. Journal of Colloid and Interface Science. 446, 133, 2015.

18. EL-SAYED E.M., TAMER T.M., OMER A.M., MOHY ELDIN M.S. Development of novel chitosan schiff base derivatives for cationic dye removal: methyl orange model. Desalination and Water Treatment. 1, 2016.

19. ALZAYDIEN A.S. Adsorption of methylene blue from aqueous solution onto a low-cost natural Jordanian Tripoli. American Journal of Environmental Sciences. 5, 197, 2009.

20. SAED U.A., MOHAMMED HUSSEIN ALI NAHRAIN, AHMED ADNAN ATSHAN. Adsorption of methylene blue dye from aqueous solution using Can papayrus. Journal of Babylon University/Engineering Sciences. 22, 218, 2014.

21. JEYAVATHANA SAMUEL, SHANTHI S., VASHANTHA R. Utilization of agro-waste material as potential adsorbent for removal of $\mathrm{Cu}(\mathrm{II})$ and $\mathrm{Ni}(\mathrm{II})$ ions from aqueous phase. Indian Journal of Advances in Chemical Science. 4, 346, 2016.

22. UNAL GECGEL, OSMAN UNER, GUNEY GOKARA, YUKSEL BAYRAK. Adsorption of cationic dyes on activated carbon obtained from waste Elaeagnus stone. Adsorption Science and Technology. 34, 512, 2016.

23. JIREKAR D.B., ARIF ALI PATHAN, MAZAHAR FAROOQUI: Adsorption studies of methylene blue dye from aqueous solution onto Phaseolus aureus biomaterials. Oriental Journal of Chemistry.30, 1263, 2014.

24. RAHMAN M.A., RUHUL AMINN S.M., SHAFIQUL ALAMA.M. Removal of methylene blue from waste water using activated carbon prepared from rice husk. Dhaka Univ. J. Sci. 60, 185, 2012.

25. EI-WAKIL A.M., ABOU EI-MAATY W.M., AI-RIDHA OUDAH A.A. Methylene blue dye removal from aqueous solution using several solid stationary phases prepared from papyrus plant. J Anal Bioanal Tech. 13, 1, 2015.

26. AMRHAR O., NASSALI H., ELYOUBI M. S. Adsorption of a cationic dye, methylene blue, onto moroccan illitic clay. J. Mater. Environ. Sci. 6, 3054, 2015.

27. EL-MAGHRABY A., EL DEEBH.A. Removal of a basic dye from aqueous solution byadsorption using rice hull. Global NEST Journal. 13, 90, 2011.

28. MANOJ L.M., DILIPH.L. Adsorption of methylene blue dye onto activated carbon prepared from Pongamia pinnata seed. International Journal of Engineering Research and Technology. 3, 1216, 2014.

29. TIMI TARAWOU, EREPAMOWEI YOUNG, DIEPREYE ERE. Adsorption of methylene blue dye from aqueous solution using activated carbon produced from water hyacinth in a fixed- bed column system. Sch.Acad.J.Biosci. 2, 607, 2014.

30. JABBAR H. AL-BAIDHANYL, SIMAA T. AL-SALIHY. Removal of methylene blue dye from aqueous solution by using commercial granular activated carbon with different types of adsorbers. Mesop.environ. j. 2, 1, 2016.

31. ASEEL M. ALJEBOREE, ABBAS N. ALSHIRIFI, AYAD F. ALKA. Kinetics and equilibrium study for the adsorption of textile dyes on coconut shell activated carbon. Arabian Journal of Chemistry. 1, 2014.

32. DADA A.O., OLALEKAN A.P., OLATUNYA A.M., DADA O. Langmuir, Freundlich, Temkin and DubininRadushkevich isotherms studies of equilibrium sorption of $\mathrm{Zn}^{2+}$ unto phosphoric acid modified rice husk. IOSR Journal of Applied Chemistry. 3, 38, 2012.

33. MUHAMMAD Z. IQBAL., AHMED A. ABDALA. Thermally reduced graphene: synthesis, characterization and dye removal applications. RSC Adv. 3, 24455, 2013.

34. NEERAJ JAIN, DWIVEDI M.K., ASHOK WASKLE. Adsorption of methylene blue dye from industrial effluents using coal fly ash. International Journal of Advanced Engineering Research and Science. 3, 9, 2016.

35. YUH-SHAN HO, MALARVIZHI R., SULOCHANAN. Equilibrium isotherm studies of methylene blue adsorption onto activated carbon prepared from Delonix regia pods. Journal of Environmental Protection Science.3, $11,2009$.

36. DANIEL S., SYED SHABUDEEN P.S., BASKARA. Studies on characterization and removal of methylene blue with Delonix regia plant litters activated carbon encapsulated nano metal oxide. Journal of Environmental Biology. 36, 933, 2015.

37. HUAYUEZHU, YONGQIAN FU, RU JIANG, JUN YAO, LI LIU, YANWEN CHEN, LING XIAO, GUANGMING ZENG. Preparation, characterization and adsorption properties of chitosan modified magnetic graphitized multi-walled carbon nanotubes for highly effective removal of a carcinogenic dye from aqueous solution. Applied Surface Science. 285, 865, 2013.

38. SUNANDA SHARMA, TIWARI D.P. Model-fitting approach for methylene blue dye adsoption on Camelina and Sapindus seeds-derived adsorbents. Adsorption Science \& Technology. 34, 565, 2016. 
